\title{
Building paradise on the Hill of Hell in Assisi: Mountain as reliquary
}

\author{
Darrelyn Gunzburg
}

The town of Assisi in Umbria, Italy, located on a sloping and precipitous mountain ridge halfway up the dome-shaped, wood-covered sides of Mount Subasio, has long been known as the birthplace of Franciscanism. Today the Basilica that houses the human remains of St Francis (c.1181/2-1226), the founder and leader of the Friars Minor, draws pilgrims and visitors alike, either to worship or admire the beauty of the architecture and fresco schemes. This influx of people makes Assisi one of Italy's prime tourist attractions. It wasn't always so. The journey to its transformation is also an exploration of the creation of a sacred and religious landscape via one man, St Francis of Assisi, one of a handful of historical figures associated with a town and mountain. ${ }^{1}$

This chapter thus investigates a unique human conversation with a mountain and how mountainous land that a community considered wild and barbaric can be changed by what they buried in it. It also explores what is believed about human remains that are buried, and how burials in such terrain affect a people's activities around the mountain and thus change the dynamics between human and mountain. It centres around the events that occurred following the death of St Francis and the desire by the Franciscan brothers to create a lasting monument to his memory via his human remains. St Francis was considered to be a phenomenon of his time and his life was full of paradox. A small, dark, nuggety man, born to a wealthy cloth merchant, he was educated as a youth and dreamed of being a knight, yet in adulthood he lived a life of poverty, dressed only in tunic, rope belt, and sandals. ${ }^{2}$ Although actively engaged with towns, St Francis sought inner peace in a hermitage, Eremo delle Carceri, 4 kilometres from Assisi, built on a rocky outcrop in a steep forest gorge 791 metres above sea level, and higher up the steep slopes of Mount Subasio. His other sanctuary 
was at La Verna, on Mount Penna, an isolated mountain of 1,283 metres situated 113 kilometres north-west of Assisi in the centre of the Tuscan Apennines above the valley of the Casentino in central Italy. He traversed a wide section of the Apennines and the places that he made his retreats created what Tim Ingold would call 'a node in a matrix of trails. ${ }^{3}$ Living through the century that saw the rise of universities, he rejected scholarship and books. As economic wealth increased and the first ducats, florins, and gold crowns were minted, he had a deep loathing for money and the greed and avarice that it carried. ${ }^{4} \mathrm{He}$ found inspiration in the natural world and he actively encouraged peace in a time full of turbulence and strife. He was instrumental in changing one of the major courses of philosophical religious thinking. In death, his final resting place - the extreme western flank of the town of Assisi, Italy - positioned the location as a pilgrimage site. As a result of this man and the afterlife of his body, a multitude of people drawn to his way of thinking have engaged in various conversations with this mountainous location. This chapter considers those 'conversations' through the themes of bodies, burials, and bones, and how mountain landscapes shape and are shaped by the people who live among them and whose stories become mythically entwined with place and landscape.

\section{Place, map, landscape}

Place, according to E. V. Walter, is 'a location of experience; the container of shapes, powers, feelings, and meanings. ${ }^{5}$ Far from being neutral, a place is one that is imbued with meaning. That framing is further inflected by Christopher Tilley, who noted that the meanings that people placed upon or into a location created an attachment to it. ${ }^{6}$ Attachment was achieved in several ways. Through regular encounter, continued and consistent movement to and from, through and within a place, natural objects or topographical features generated familiarity and became entwined into story, which further embedded those memories and experiences. Furthermore, place had a way of acting upon a person through what was remembered, the incidents that occurred there or the journeys undertaken through it. Place became, as it were, a receptacle for where events happened. Naming also invested a place with meaning. 'Place names', Tilley wrote, 'are of such vital significance because they act so as to transform the sheerly physical and geographical into something that is historically and socially experienced' and thus 'in a fundamental way names create landscape.7 This becomes noticeable from observing twenty-first-century maps. Blank spaces on a map are places 
that hold no memories or experiences for the map-maker, hence although they exist geographically, they have not been identified by name. Furthermore, while any place on conventional maps can be designated by longitude and latitude, the reality is that places are relational. As Walter observed, 'We learn where it [a place] is in another sense by its relation to established places.' It is uncommon to say 'in $23.4162^{\circ} \mathrm{N}$ and $25.6628^{\circ} \mathrm{E}$ ' or 'near $48.8566^{\circ}$ and $\mathrm{N}, 2.3522^{\circ} \mathrm{E}$ ', for unless a person works with map coordinates, such terminology is meaningless. The former coordinates, however, become meaningful when changed to the phrase 'in the Sahara Desert', which implies qualities of hot and dry, wind and sand, nomads and camels; the latter coordinates when identified as 'near Paris' raise images of the 2019 fire in the roof of the cathedral of Notre-Dame, the late nineteenth-century ironwork of the Eiffel Tower, waiters serving café crème on the Île Saint-Louis, the energy and stimulus of the Marais, the wide boulevards, and the many bridges. ${ }^{8}$ Alfred Korzybski argued, A map is not the territory it represents, but, if correct, it has a similar structure to the territory, which accounts for its usefulness.'9 A contemporary map of places can therefore help in planning a journey and, by naming the sites, buildings, or monuments found along the way, identify objects that create that place. They offer nothing in terms of the people or the life forms that one may encounter.

Medieval maps gave greater certainty to place because, as Michel de Certeau pointed out, they were stories that exemplified and illustrated journeys and included striking and unforgettable experiences. ${ }^{10}$ Ancient maps offered a similar benefit. The Classic of the Mountains and Rivers, a book from ancient China, c.600 BCE, said to be the oldest travellers' guide in the world, is a book of mythic geography. Walter, taking inspiration from the work of Joseph Needham, pointed out how the Classic described the Nine Cauldrons of Hsia, 'metal surfaces covered with pictures that represented the nine provinces of the country'. ${ }^{11}$ It was written to give people guidance on how to recognize good and evil spirits in the physical features of the land, enabling cross-country journeys to be undertaken without fear by showing travellers where to tread safely and how to avoid giving offence to the landscape spirits through inadvertent intrusion into territory that was not safe. ${ }^{12}$ Walter recognized that, while what was being portrayed may have appeared, to a twenty-first-century reader, to be fantastical, the descriptions in the book nevertheless illustrated the spirits of places and the places of spirits. Spirits that lived in the landscape described the qualities experienced by the traveller, thus these maps captured how people felt regarding those places. Such maps emerged from reading landscapes as living territories and offered travellers ways to exist in them and how to journey through them. While this chapter is 
not about mapping per se, in Assisi, it is possible to appreciate the development of such qualitative landscape mapping through the life and afterlife of St Francis and his connection with Mount Subasio.

\section{Assisi, inferno, wild}

Assisi is located above the plains on a sloping and precipitous ridge halfway up the dome-shaped, wood-covered slopes of Mount Subasio, Umbria, part of the Apennine mountains extending the length of peninsular Italy (Figure 4.1). When St Francis was alive, the area beyond the town was considered to be wild and barbaric. It was known as the Collo dell'Inferno, or 'Hill of Hell, due to it being

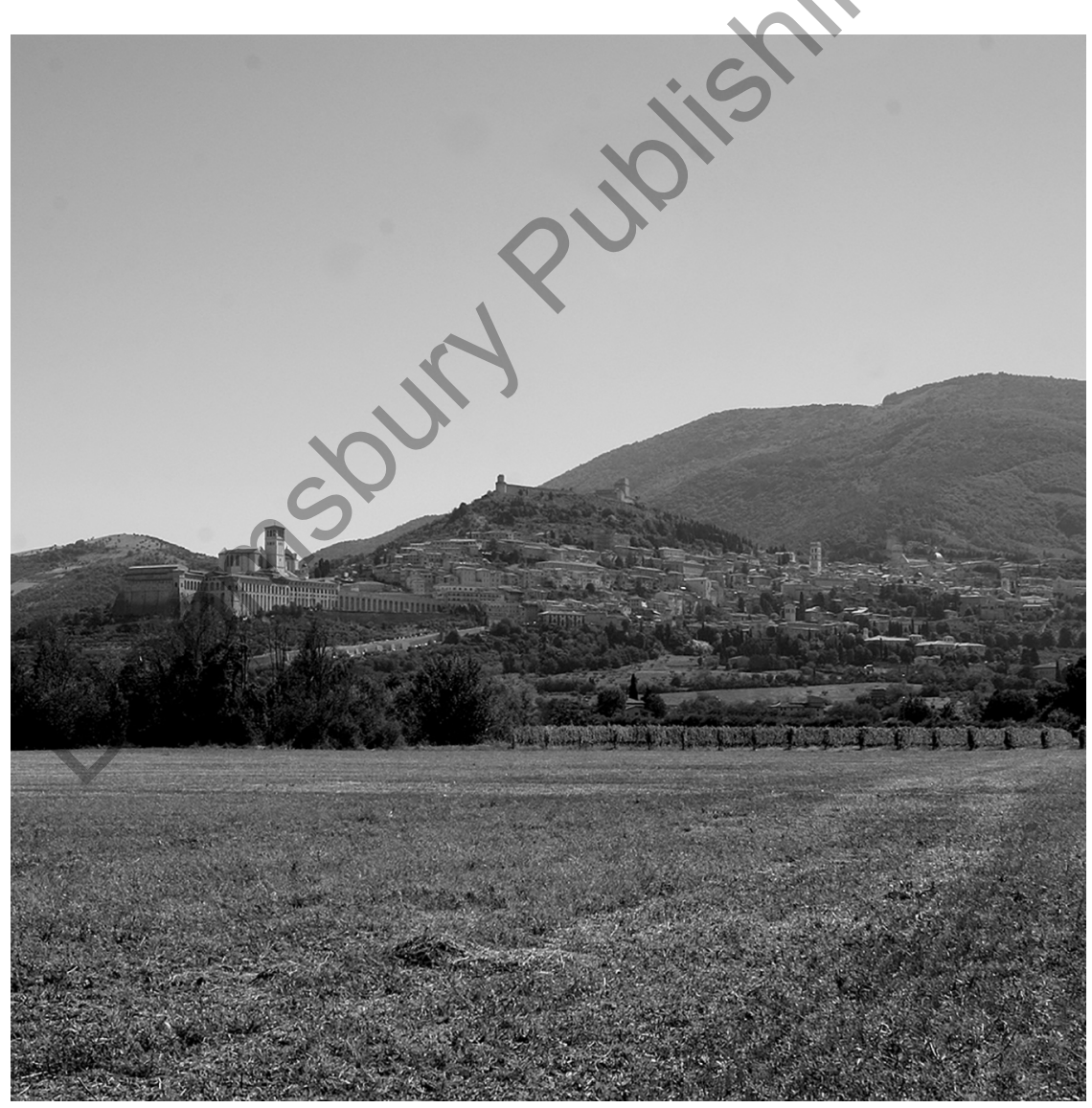

Figure 4.1 View from the south looking towards the Basilica di San Francesco and the Collo dell'Inferno, the town of Assisi, and Mount Subasio. Photo: D. Gunzburg. 
a place for the torture and execution of the condemned. ${ }^{13}$ It could, however, simply have been an aberration of the word inferius meaning 'lower', as the location was situated further down the rocky outcrop from Assisi overlooking the Tiber valley towards Perugia (Figure 4.2). ${ }^{14}$

The term 'wild' and its connotations are worth pursuing, however. Robert Macfarlane initially identified wild as 'somewhere boreal, wintry, vast, isolated, elemental, demanding of the traveller in its asperities. ${ }^{15}$ In his haptic exploration of wild places, however, Macfarlane came to realize that, rather than somewhere distant and remote, without a past and unnoticed, the wildness of natural life was everywhere, the power and strength of a presence that was energetic, and chaotic, in a state of becoming. ${ }^{16} \mathrm{He}$ applied the term to the life that inhabited a place, the weed and tree root both finding ways to gain upward thrust through pavement and tarmac to air and sustenance. He saw it as a dynamic experience, one that was not limited or obstructed, but pushing skyward and moving forward.

In medieval Italy, towns and city states perched precariously along narrow ridges, ringed with defensive walls and gates. Towns in Italy today still maintain their hazardous hold on the land, yet in the medieval world, the land beyond a medieval city wall was held to be wild and dangerous, a place for bandits and criminals, lepers and the poor. Wild places beyond city gates acquired another quality through their connection to the human experience of Jesus of Nazareth, who had been crucified at Golgotha, 'the place of the skull' (Mt. 27.33; Mk 15.22; Lk. 23.33; and Jn 19.17), and died as a criminal beyond the city wall of Jerusalem (Heb. 13.12) visible to all passers-by (Mt. 27.39 and Mk 15.29). Jesus was the exemplar that St Francis followed, so much so that he became known as Franciscus alter Christus. ${ }^{17}$ According to Silvestro Nessi, in 1277, Fra Raniero d'Arezzo (d. 1304), a contemporary of the companions of St Francis, heard them say that St Francis had explicitly requested to be buried on the Hill of Hell, following the way of Jesus. When the companions of St Francis pointed out the disreputable status of the Collo dell'Inferno, he had replied: 'If the place is now called the Hill of Hell, it will be called the Gate of Heaven and the Entrance of Paradise.'18 The story may be apocryphal; Antonio Cadei has suggested that Pope Gregory IX (1145-1241) intentionally named it thus to evoke an old legend. ${ }^{19}$ Nevertheless, the story has now become locked into this landscape and, as Walter and Tilley would term it, woven into meaning.

St Francis was, however, already accustomed to wild places. The hermitage at Eremo delle Carceri, where St Francis came to pray and contemplate, still contains the stone bed where he slept. It originally consisted of a series of caves and an oratory built on a rocky outcrop in a steep forest gorge 791 metres above 
sea level. The sanctuary at La Verna was also used as a retreat for contemplation by St Francis. It was given to him in 1213 by Count Orlando Cattani of Chiusi of La Verna, who used the words 'molto solitario e salvatico' ('much isolated and wild') to describe the place. ${ }^{20}$ These places were in keeping with St Francis's belief that to live in the world was to live an ecological life, in joy and harmony with the natural surroundings. He strove to implement a life underscored by an ecological perspective, one that recognized the divine presence in all creatures, based in joy rather than sadness (accedia). ${ }^{21}$ He described this joy in The Canticle of Brother Sun: 'Praised be you, my Lord, with all your creatures', and he expressed his habitat both as qualities and as familiars, members of his family who worked together harmoniously and, in so doing, sustained life: 'Sir Brother Sun,/Who is the day and through whom You give us light,/ And he is beautiful and radiant with great splendour; and bears a likeness of You, Most High One'; Sister Moon and the stars - 'clear and precious and beautiful'; Brother Wind and the air and weather that was 'cloudy and serene'; Sister Water, 'useful and humble and precious and chaste'; Brother Fire, who lit the night and who was beautiful and playful and robust and strong'; Sister Mother Earth, who 'sustains and governs us,/ and who produces various fruit with coloured flowers and herbs'; and finally Sister Bodily Death 'from whom no one living can escape.22 Macfarlane identified a similar joy in the plethora of senses that assailed him as he walked the old ways of Britain in 2012 in search of the stories created by ancient paths - the temperature of the air, the dynamic display of natural light, the quality of surfaces, the smells, and 'the uncountable other transitory phenomena and atmospheres that together comprise the bristling presence of a particular place at a particular moment. ${ }^{23}$ Being in a landscape, for Macfarlane, was to be immersed in a present of qualities, perspectives, and substances:

I prefer to think of the word as a noun containing a hidden verb: landscape scapes, it is dynamic and commotion causing, it sculpts and shapes us not only over the course of our lives but also instant by instant, incident by incident. ${ }^{24}$

On 30 March 1228, the owner of the Hill of Hell, Simone da Pucciarello, who was, according to tradition, a faithful companion of St Francis from his youth, donated a plot of this wild land beyond the gates of Assisi to enable a burial site to be constructed. Since Franciscans were prohibited from owning any property, Pope Gregory IX, in the name of the Holy See, took on the patronage and ownership of both church and convent. On 17 July 1228, one day after St Francis was canonized and less than two years after his death, Pope Gregory laid the first stone. ${ }^{25}$ Despite St Francis declaring that the tiny church of the Porziuncula, a 




Figure 4.2 View of the Basilica di San Francesco today, taken from Mount Subasio looking towards the west and the plains. Photo: D. Gunzburg.

mile south of the walls of Assisi, was to be the head and mother church of the Roman Catholic Order of Friars Minor, Pope Gregory decided otherwise, and on 22-April 1230 he awarded that role to the Basilica that was yet to be built. ${ }^{26}$ On 25 May 1230, on the eve of Pentecost, the body of St Francis was translated from the church of San Giorgio to the previously wild and barbaric place beyond the city walls of Assisi (Figure 4.2).

\section{Bones and saints}

While the proper place of cemeteries in the Roman world was beyond the walls of cities, by the end of the sixth century the landscape of cemeteries had 
undergone a ground change and, catalysed by the graves of saints, reframed the centres of religious life. They became places where tomb and altar were joined, glorified by the architecture and art that created the sites and made accessible to the whole community via symbolic rites. ${ }^{27}$ By offering access in this way burials became much more than customs surrounding the care of the dead and graves became much more than monuments tended by the family on whom rested the incumbent agreement of ritual and closure around bodily separation. The graves of the saints were where the community came to meet the saint as intercessor, thus creating a place where the community could be in dialogue with him or her. This joining of earth with heaven thought to occur at the gravesite occurred through a phenomenon Peter Brown termed praesentia, the physical presence of the holy. ${ }^{28}$ The belief that at the grave one could meet this presence was exemplified by the inscription on the tomb of Saint Martin of Tours (316 or 336-8 Noyember 397):

Hic conditus est sanctae memoriae Martinus episcopus

Cuius anima in manu Dei est, sed hic totus est

Praesens manifestus omni gratia virtutum.

Here lies Martin the bishop, of holy memory

whose soul is in the hands of God; but he is fully here,

present and made plain in miracles of every kind (trans. Brown). ${ }^{29}$

Once this idea took hold in the Patristic period, it resisted change until well after the Reformation. ${ }^{30}$ Although there are saints whose bodies on exhumation have been found to be incorrupt, such as St Zita (c.1218-72), St Rita of Cascia (1381-1457), and St Virginia Centurione (1587-1651), among others, for the most part, bones are what are left in the tomb. Bones below the ground, as was the case with St Francis, are different. Although the aim of this chapter is not to encompass the full extent and significance of the life of St Francis, nor the meaning of his body after death, nevertheless, a summary of these events will place the reception of that life in context.

\section{St Francis - hagiography, biography, context}

The events of that life are well known, despite the loss of valuable primary source documents, such as the first 'Rule' that St Francis wrote in c.1209, and several of St Francis's personal letters, combined with the fact that St Francis himself did not write his own story. This has made it difficult to piece together an accurate Franciscan historiography. In addition, due to the proliferation of biographies, 
the general chapter of the Franciscan Order of 1260 requested Saint Bonaventure to write the official hagiography - the Legenda major. This was approved by the Order in 1263, followed by a resolve in 1266 to obliterate all earlier biographies. Other works have since emerged, such as Thomas of Celano's first biography (Vita prima). ${ }^{31}$

St Francis was born c.1181/1182 in Assisi to Pietro di Bernardone, a prosperous cloth merchant, and Pica de Bourlemont, a French noblewoman from Provence. As stated earlier, his original ambition was to find glory as a knight. Over the course of a handful of years, visited by dreams, and an illness which gave him time to think about the commensality of body and mind, gradually a conversion took place. There were several catalysing moments in St Francis's life that shaped him and brought him closer to the life he envisaged for himself, a life that sought to protect and defend core values despite the material changes he saw around him. They created what Jacques Le Goff has identified as a man who acted as 'an eddy in the rising tide of material comfort. ${ }^{32}$ This new materiality of change was one that had been incrementing since the year 1000 when, over a period of years, population increase in north and central Italy generated towns. Initially these were villages accreted around church and castle; gradually the focus on military and administrative concerns shifted to an economic, political, and cultural emphasis. Towns became the focus for new work processes and new economic exchange. Merchant bankers took over the handling of money from monasteries, and Jews and a growing number of Christian merchants became consumer lenders, also known as usurers. As Le Goff has summarized, 'Economic and social inequality was based no longer on birth and family, but on possessions and property, ownership of land and buildings in town, of rents and rates in the form of money. ${ }^{33}$ Craftsmen and merchants (arti) combined with political organizations (comuni) to change the fabric and make-up of urban centres.

The first symbolic rejection of St Francis's dream of becoming a knight occurred on his way to war in Apulia in 1205 when he met an impoverished knight in meagre clothing and gave him his coat. The second occurred in 1206 when he observed the rundown church of San Damiano and, in an act of seeming irrationality, sold his father's stock of cloth, along with the horse that carried the cloth to market, to raise money for the repairs. His father being understandably enraged at this action, St Francis sought protection with the bishop of Assisi. Then, in front of his father and the priest, he removed all his clothes in a gesture that emblematized cutting ties with his past. Subsequently, while praying in San Damiano, the Romanesque rood cross spoke to him, urging him to repair God's 
ruined house. Taking this as a literal injunction, St Francis picked up a trowel and taught himself masonry. The completion of his irrevocable change came in 1209 at the age of 26 or 27, during a sermon at the Porziuncula when he heard the words of Matthew 10 anew. In response, he discarded his shoes and staff, tied his tunic with a rope, and began his life as mendicant preacher. Although he often sought solitude and space at La Verna and Eremo delle Carceri, he also chose to engage with the living, and thus took the Order on a different direction to that of the monasteries, which operated as a separative existence. In 1224, at La Verna, when meditating on a vision of a man with six wings with open arms and joined feet, fixed to a cross, he received the stigmata, becoming the first Christian to do so (Figure 4.3). He was a man who always suffered with poor health and in the intervening two years until his death he endured blinding headaches and impoverished eyesight.

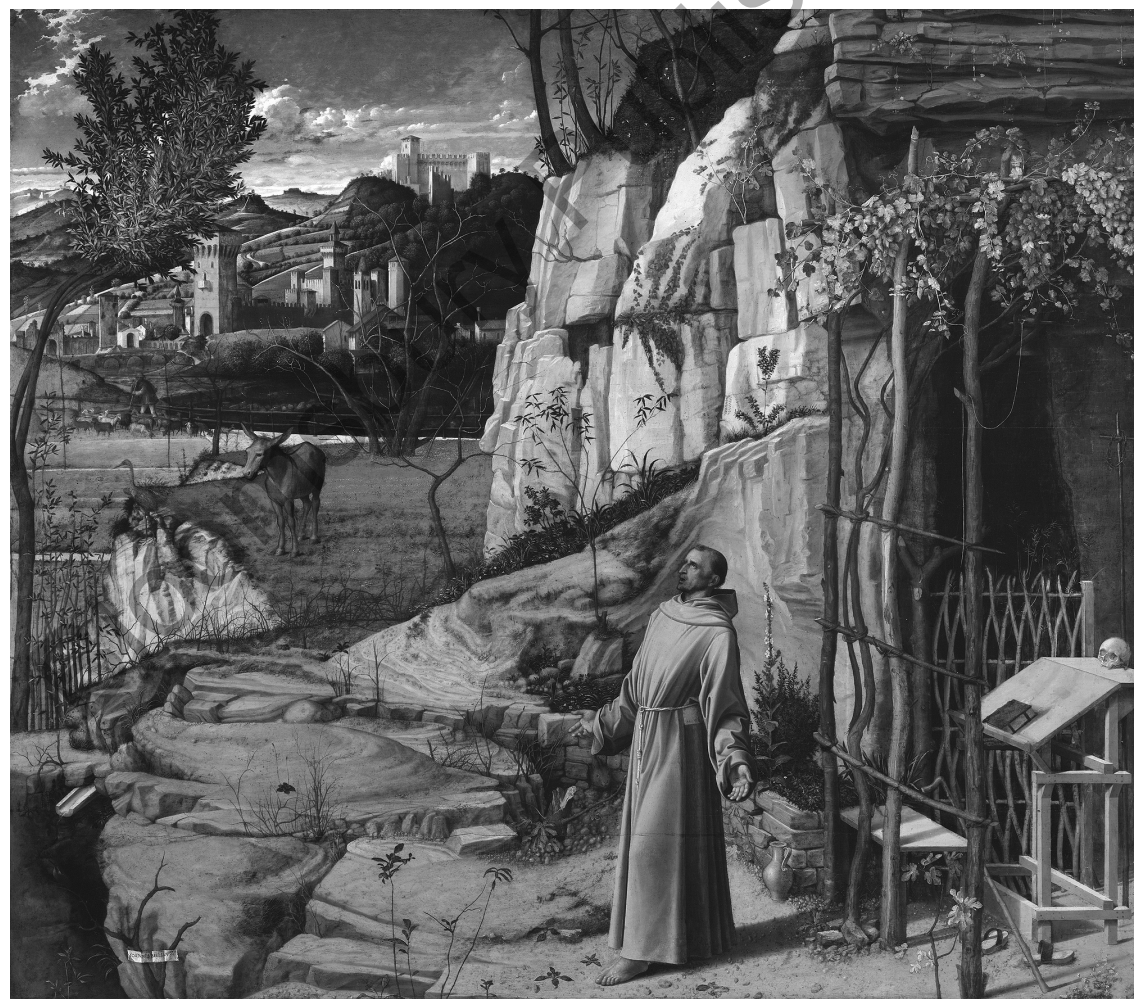

Figure 4.3 Giovanni Bellini (c.1424/35-1516), St. Francis in the Desert, c.1476-8, oil on panel, $491 / 16 \times 55$ 7/8 inches $(124.6 \times 142 \mathrm{~cm})$. Image: Copyright The Frick Collection. 
When he was close to death, his wish to return to the Porziuncula was jeopardized by the fact that the closest road passed by Perugia. His companions were deeply concerned that he might be kidnapped by the Perugians, and his burial bring them profit from pilgrimage. ${ }^{34}$ Saintly bodies were also stolen for the relics they could yield through bodily division. Organs such as the heart were prized. Bodies could also be boiled to remove the flesh so that bones could be distributed, such as occurred with Saint Louis XI of France (1214-1270) and Saint Thomas Aquinas (1225-1274). ${ }^{35}$ With his death imminent, his companions were determined that his body would not be used for profit and would be kept whole. A safer, more circuitous route back was taken and his death in the Porziuncula oceurred on 3 October 1226. In accordance with his wishes, he was laid out naked on the floor and his body covered with dust and ashes. The funeral was held the following day and his body was buried at the church of San Giorgio, now a chapel in the basilica of Santa Chiara, in the town of Assisi.

Evidence from a variety of post-mortem miracle scenes painted on early Vita panels depict St Francis's coffin as wooden, rectangular, and raised off the ground by four legs. ${ }^{36}$ The literature is, however, silent as to where in San Giorgio he was buried. In the decomposition that follows death, nature is highly expedient. Decay of the body occurs in stages and in the process, the body moves from corpse to cadaver to skeleton. In the first twenty-four hours autolysis occurs. The body looks fresh, yet internal organs begin to break down. After two or three days when active bacteria distend the body with odorous gases, it begins to decompose. In order to facilitate drainage of liquids from the decomposing body to avoid sanitary and health problems, a hole would be drilled into the base of the coffin. Black putrefaction develops when the corpse turns black and shrinks from escaping gases. This is followed by fermentation when the body begins to dehydrate and releases strong odours. In a state of dry decay, all the moisture of the body disappears, and decomposition is significantly reduced. The corpse has now become a cadaver. ${ }^{37}$ It takes a long time to form bones, however.

\section{Found in translation}

From the day of translation on 25 May 1230 onwards, controversy surrounded the exact whereabouts of the tomb of St Francis and in the confusion that followed, deliberate or otherwise, the ensuing motif of 'the secret tomb' gained traction within the Order's collective memory. Over nearly six hundred years of time, stories of the tomb and the search to locate the shrine's exact placement 
compounded; these have been comprehensively reviewed by Donal Cooper. ${ }^{38}$ Two failed searches occurred, one in 1755 and a second in 1802-3. In the interim, doubt was even cast by the Observant branch of the Order over whether the tomb actually existed. ${ }^{39}$ Fifteen years after the second unsuccessful search, Pope Pius VII (b. 1742 and head of the Catholic Church and ruler of the Papal States from 14 March 1800 to his death in 1823) sanctioned an expedition led by the Papal Commissioner for Antiquities, Carlo Fea. This one was successful. On 12 December 1818, after fifty-two nights of digging, workmen reached an iron grating beneath which was a stone coffin and skeleton. Cooper has rightly noted the debt modern scholarship owed to Fea for his meticulous notes and careful plan and cross-section drawings of the area beneath the high altar of the Lower Church and these notes indicate the great care that was taken to conceal the body from view. ${ }^{40}$

Bartolomeo da Pisa in his De Conformitate vitae Beati Francisci ad vitam Domini Iesu (1385-90) emphasized the link between the tomb of St Francis and the tomb of Christ: 'As Christ's tomb was sealed and watched by guards, so St Francis's tomb has been sealed, to prevent his body ever being visible to anyone.41 Cooper has further observed that, while St Francis's burial below the high altar was an outmoded style for thirteenth-century Italian shrines, such a placement may have reflected Early Christian martyr burials, as noted in Revelation 6:9, and thought appropriate for St. Francis's standing as head of the new Order. ${ }^{42}$ This below-ground burial was also motivated by the fear of theft. Whatever the reason, this is what Fea found.

To create the burial place, a small chamber measuring approximately 380 square centimetres, although made smaller by rubble in-fill, was carved into the mountain side. St Francis was placed into a simple stone sarcophagus, probably of Early Christian origin, around which was placed a wrought iron cage or arca, on top of which a free slab of travertine limestone served as a lid. Leaving a small gap above the sarcophagus, two enormous slabs of travertine limestone were then cemented together one on top of each other and set into the walls of the cavity, and placed onto three iron bars, to hold their weight separate from the sarcophagus below them. The burial chamber was surrounded by rock on all four sides, but a small cavity was created above the cemented travertine slabs. Once the chamber was sealed, the only indication that established the location of the now-hidden tomb was the position of the high altar of the Lower Church. Thus for pilgrims, the altar served as a physical synecdoche for the saint, and became the place where the community gathered to meet him and to be in conversation with him. 
Although buried into rock, which suggests a degree of permanence and immovability, the tomb as a point of stillness also became a pivot point for thinking about the life of St Francis, what he represented, and his journeys across and through this mountainous landscape. For as Walter observed, 'Human experience makes a place, but a place lives in its own way. Its form of experience occupies persons - the place locates experience in people. ${ }^{43}$ The tomb was set into a 'wild' place on the side of the mountain with plains below and wooded landscape around, thus the place amplified the encounter. The impact of St Francis's death was that it drew followers to pay homage to the places that shaped him: the hermitage at Eremo delle Carceri, the sanctuary at La Verna, the forest and mountainous area of Greccio where St Francis celebrated the crib at Bethlehem, the tiny church of the Porziuncula, and the church of San Damiano where the rood spoke to him. Ingold has described the complex of interwoven trails which people produce to create their life a 'meshwork'. Ingold in turn borrowed the term from Henri Lefebvre who defined 'meshwork' as 'the reticular patterns left by animals, both wild and domestic, and by people (in and around the houses of village or small town, as in the town's immediate environs). ${ }^{44}$ The itinerant preaching that was to become St Francis's way of life created such a meshwork of habitation, weaving his life with this living mountainous landscape around Assisi. In traversing the landscape to reach the places that had shaped him via such a meshwork, pilgrims opened themselves to the possibility of the landscape 'scaping' them as it had St Francis.

\section{The mountain as reliquary}

In their exploration of the properties that exist essentially or permanently in bone, Cara Krmpotich, Joost Fontein, and John Harries asked not what it is that people do with bones but rather 'what do bones do to people?'45 As noted previously, the bones of a saint sanctify place. Thus, the raised tomb as a place for holding the relic of the saint becomes venerated. As the place where the tomb is situated draws people to it, so this becomes an established pilgrimage site. The raised tomb envisioned in 1233 for St Dominic in Bologna was the style that became influential for thirteenth-century shrines of saints. ${ }^{46}$

Once the body is in the ground, however, the soil itself becomes a living receptacle for the decomposing body. Meaning becomes interred into bones, into soil, into place. Robert Pogue Harrison has suggested that humans bury their dead 'to humanize the ground on which they build their worlds and found 
their histories. ${ }^{47}$ The body of a saint changes the trajectory of this thinking slightly. Human yet more-than-human in their holiness and closeness to God, once buried in the ground, the bones of saints acted as conduits for change. Harrison rested on Giambattista Vico's (1668-1744) etymologizing of humanitas ('humanity'), humando ('burying'), and humus ('earth' or 'soil'). Carrying this further, in the case of a saint, bone, rock, and soil join together as transformative agents and all that a monument on the burial ground can do is point to what we, as humans, place into the ground to keep it safe and retain its memory. As long as the tomb of St Francis was hidden underground, body, bones, soil, and place created a different perspective, one that at least until 1818 was unique, for the sacred relic was invisible, totally hidden. It was, as Antonio Cadei observed, 'replaced by a space that represents it rather than containing it'. 48 'The high altar placed over it in the Lower Church, pointed to it, but as few people had seen it directly, a degree of trust was required. Corroboration of such trust can be seen in Cooper's research where, working from the insights of Niccolò Papini, OFM Conv., he observed an entry from the Sacro Convento's archive dated 23 June 1380. The entry established that Pietro di Giovanni had been present at a Mass in honour of St Francis as part of his fulfilment of a pilgrimage by proxy, and that he had 'placed his hand on the altar beneath which lies the body of the Most Holy Father Francis, in the presence of a number of trustworthy friars from this convent. ${ }^{49}$ As Cooper noted, 'Pietro di Giovanni touched the altar mensa as he might the Saint's tomb.' The high altar-tomb reversal also meant that it could produce miracles. In 1308 Francesco Bartoli described how a female pilgrim was cured when she placed her hand on the mensa: 'posita manu sua super altari in quo Corpus beati Francisci conditum requiescit.'50

In addition, a small iron grate set into the uppermost step of the altar platform facing the nave allowed the pilgrim kneeling on the steps of the high altar a shadowy view of the vaulted chamber below. In this they were required to have faith that the chamber contained the body and which, as noted above, the 1881 excavations revealed that it did indeed do so, but clearly much deeper than anticipated. Since it was lit by oil lamps this space was known as the buca delle lampade. ${ }^{51}$ Kneeling at the high altar, experiencing the contrast of glowing altar lamps in the dim light, the pilgrim would have been encouraged to reflect on the stories of St Francis's life in the place of his death, a sensory experience encompassing not only the visual but also the aural sounds of prayer, weeping, sighing, breathing, and the smell of incense and burning candle. It became the location of experience to which Walter referred and imbued with the attachment discussed by Tilley. The place became the receptacle for the events 
that had occurred there, bound to the bones, but encouraging pilgrimage across the mountainous area to the places that were meaningful to St Francis: the Porziuncula, Eremo delle Carceri, Mount La Verna, the church of San Damiano, and Greccio, among others. The point of stillness at the high altar encouraged the faithful to think widely about the connection between the sensory -what was seen and felt - the vita - what was known, understood, and propagated by the church about the life of St Francis - and the materiality of the place - tomb, Basilica, town, and the mountains that created the meshwork of his life. In this regard, Mount Subasio changed from wild (Collo dell'Inferno) to buried (tomb/ Lower Church high altar/Basilica) to container, and by becoming a vessel that held a precious relic, the mountain became a reliquary.

In discussing body-part reliquaries, Cynthia Hahn recognized how subjectobject reversal applied to the container and the contained, that the reliquary facilitated the power of the relic and, at the same time, gave it potency and thus, over time, the status of one supplanted the other. The reason for this was understandable since, as Hahn went on to observe, Unadorned relic bones are inexpressive, anonymous, perhaps even repugnant. Without proper identification and a cultural matrix - what medieval sources call a proper veneration - relics remain inert. ${ }^{52}$ Ultimately, Hahn argued, the reliquary functioned as a sign. The precipitous ridge of Mount Subasio could be said to have taken on a similar role - when St Francis died, the mountain became a living reliquary. Not only did it hold and contain the bones of the saint, it directed focus to the environment within which it sat (Figures 4.1 and 4.4).

When the redesigned crypt was opened in the 1824, pilgrims had previously unprecedented access to the sarcophagus. The newly cleared space created to form the crypt gave pilgrims the opportunity to process around it (Figure 4.5). Such access was fittingly summed up by Cooper: 'The modern pilgrim to Assisi experiences the tomb of St. Francis in a manner wholly unrelated to its medieval origins. ${ }^{53}$ Place, Walter observed, located experiences in people and seeing the tomb offered a different dialogue between story and stone, between the myth and the man, and an ongoing conversation based on visuality anchored the material presence of St Francis to the mountain more fully.

There is one more point to be added to this discussion regarding this conversation with this mountain. In Underland, Macfarlane offered a view of stone in deep time. Deep time he defined as that kept by 'stone, ice, stalactites, seabed sediments and the drift of tectonic plates. ${ }^{54}$ Deep time stretched so far backwards and forwards in epochs and aeons that it was almost unfathomable for the human mind to grasp. Yet in deep time, the view of rock and stone changed. 




Figure 4.4 The entrance to the Lower Church, Basilica di San Francesco. Photo: D. Gunzburg.

'We tend to imagine stone as inert matter, obdurate in its fixity', Macfarlane wrote. 'But here in the rift it feels instead like a liquid briefly paused in its flow. Seen in deep time, stone folds as strata, gouts as lava, floats as plates, shifts as shingle. Over aeons, rock absorbs, transforms, levitates from seabed to summit. ${ }^{55}$ Stone thus has its own pace. The Apennine mountain range, of which Mount Subasio is part, developed when the African and Eurasian tectonic plates crushed against each other between one hundred million years and two million years ago. ${ }^{56}$ The limestone rock that formed the mountain range was the repository from remote shallow seas that were in existence three hundred million years ago. ${ }^{57}$ The events that occurred at the beginning of the thirteenth century in Assisi culminated in the tomb of St Francis being hewn into the substrate. The nineteenth-century search for the sarcophagus took fifty-two days of digging through the rock. It 


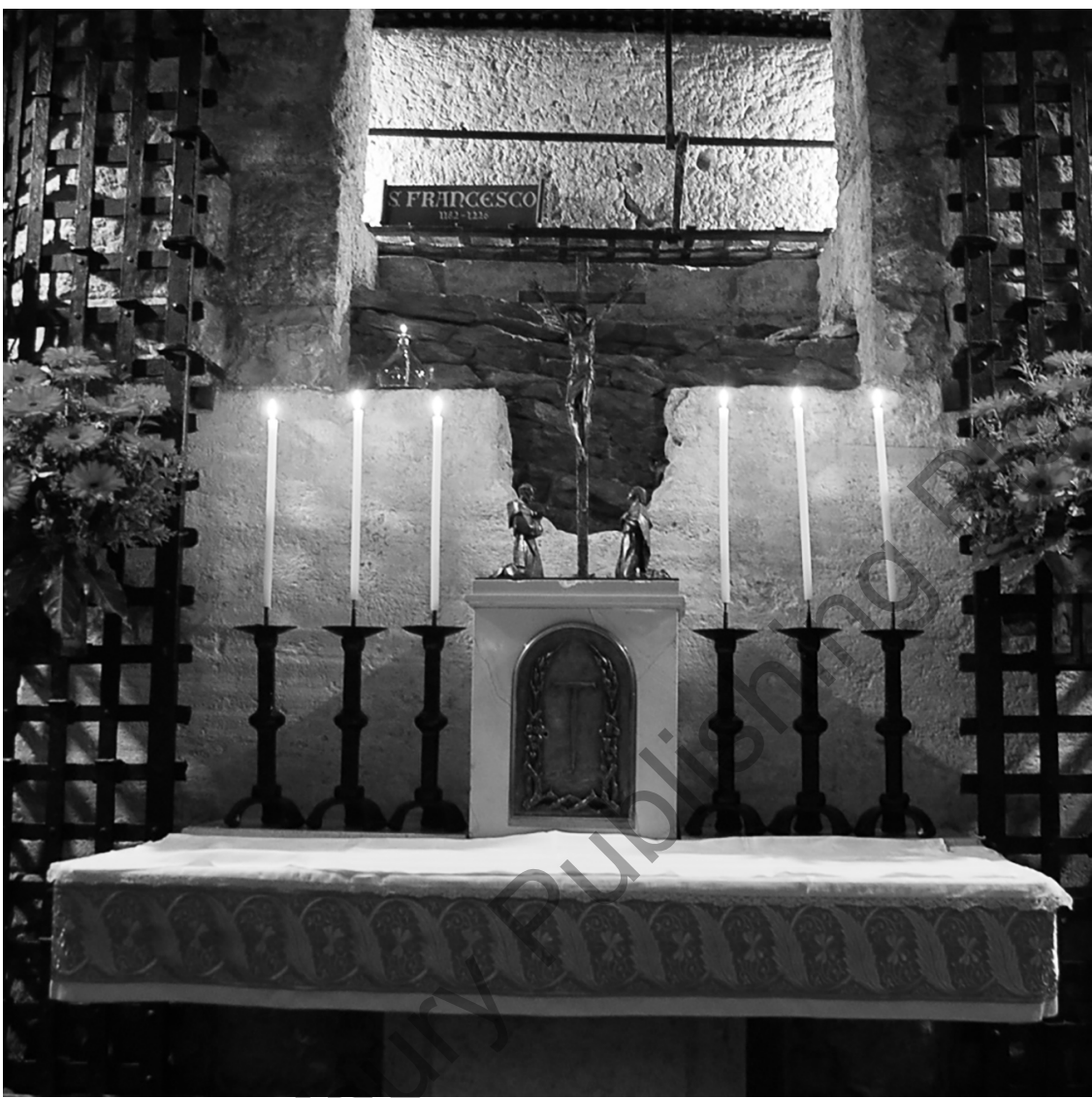

Figure 4.5 Crypt of St Francis, Basilica di San Francesco, Assisi. Photo: Martin Schmidt, https://martinschmidtinasia.wordpress.com/.

took four more years to hew the chamber of the crypt. Faith placed body and bones into deep time and anchored the sanctified space with and around St Francis. This in turn began an ecological conversation with the mountain.

\section{Conclusion}

This chapter has taken as its beginning point of exploration the fact that St Francis of Assisi is one of a handful of historical figures associated with a town and a mountain. Born in the region, he maintained a connection to it his whole life. Although his preaching took him through central and northern Italy, his pivot point of regeneration and recuperation was in the church of the Porziuncula, 
4 kilometres south of the walls of Assisi. The meshwork he created gave him anchor points or nodes at the hermitage at Eremo delle Carceri 4 kilometres south-east of Assisi, and at La Verna, 113 kilometres north-west of Assisi. Fear of theft around his body's translation and burial beneath the high altar of the Lower Church meant that throughout the medieval period it was never visible. An issue equally alive, as Cooper has noted, is thus a lack of major relics, predicated on the insistence by the Order that 'the tomb contained the Saint's whole and undivided body.58 ${ }^{58}$ More than any other saint, the coalescing of body and bone with earth and stone focused a conversation with place, mountainous land that humans considered wild and barbaric and which was changed to sacred and holy by what the community buried in it.

St Francis is famously known for preaching to the birds; those were not the only conversations he had with the natural world. This chapter has considered those 'conversations' through the themes of bodies, burials, and bones, and how mountain landscapes shape and are shaped by the people who live among them and whose stories become mythically entwined with place and landscape. In its physical state the mountainous environs that shaped St Francis, his ideas and his thinking, also created the conditions for his conversion of faith. Thus it could be said that place shaped the man. In turn, the town and its environs responded to his death and experienced a conversion of place, thus the man shaped the place. At the heart of this sequential shaping was the mountainous landscape of Assisi. It was this landscape that, as noted earlier, amplified St Francis's belief that to live in the world was to live an ecological life, in joy and harmony with the natural surroundings.

This Franciscan conversation began in the twelfth century and over the last eight hundred years has been one that has occurred in slow time, drawing people in a continuous flow to the Basilica di San Francesco in Assisi and once there, engaging them in the landscape St Francis's life. Through the mountain, this slow conversation continues to take place, make place, and create place.

\section{Notes}

1 Andre Vauchez, Francis of Assisi: The Life and Afterlife of a Medieval Saint, trans. Michael F. Cusato (New Haven, CT: Yale University Press, 2012), 3.

2 Jacques Le Goff, Saint Francis of Assisi, trans. Christine Rhone (London: Routledge, 2004), 54-5.

3 Tim Ingold, 'Ways of Mind-Walking: Reading, Writing, Painting', Visual Studies 25, no. 1 (2010): 15-23, at 16. 
4 Le Goff, Saint Francis of Assisi, 61.

5 Eugene Victor Walter, Placeways: A Theory of the Human Environment (Chapel Hill: University of North Carolina Press, 1988), 215.

6 Christopher Tilley, A Phenomenology of Landscape (Oxford: Berg, 1994), 18.

7 Tilley, Phenomenology of Landscape, 18-19.

8 Walter, Placeways, 118.

9 Alfred Korzybski, Science and Sanity: An Introduction to Non-Aristotelian Systems and General Semantics, 5th ed. (Brooklyn, NY: Institute of General Semantics, [1933] 1994), 58.

10 Michel de Certeau, The Practice of Everyday Life, trans. S. Rendell (Berkeley: University of California Press, 1984), 120-1.

11 Walter, Placeways, 118.

12 Walter, Placeways, 118-19; Joseph Needham, Science and Civilisation in China. Vol. 3, Mathemativs and the Sciences of the Heavens and the Earth (Cambridge: Cambridge University Press, 1970), 503.

13 Carla Pietramellara et al., Il Sacro Convento Di Assisi (Roma: Laterza, 1988), 6, $11,65$.

14 Antonio Cadei, 'The Architecture of the Basilica, in Saint Francis: Patriarchal Basilica in Assisi; Artistic Testimony, Evangelical Message, ed. Roberto Caravaggi (Milan: Gruppo Editoriale Fabbri, 1991), 43-76, at 72.

15 Robert Macfarlane, The Wild Places (London: Granta, 2007), 7.

16 Macfarlane, Wild Places, 316.

17 H. W. van Os, 'St. Francis of Assisi as a Second Christ in Early Italian Painting', Simiolus: Netherlands Quarterly for the History of Art 7, no. 3 (1974): 115-32, at 115 .

18 Ms. Vat. 4354, c. 108. 'Si locus ille modo vocabatur Colli Inferni erit quando vocabitur porta coeli et janua paradisi.' Silvestro Nessi, La Basilica Di S. Francesco in Assisi E La Sua Documentazione Storica, vol. 5, Il Miracolo Di Assisi (Assisi: Casa Editrice Francescana, 1994), 20.

19 Cadei, Architecture of the Basilica', 72.

20 La Verna Santuario Francescano, https://www.laverna.it/santuario/storia/ (accessed 23 September 2019).

21 Le Goff, Saint Francis of Assisi, 61.

22 Jacques Dalarun, The Canticle of Brother Sun: Francis of Assisi Reconciled, trans. Philipe Yates (New York: Franciscan Institute, 2016), 2-3.

23 Robert Macfarlane, The Old Ways: A Journey on Foot (London: Hamish Hamilton, 2012), 255.

24 Macfarlane, Old Ways, 255.

25 Nicola Giandomenico and Paolo Rocchi, Basilica Patriarcale Di San Francesco in Assisi: Il Cantiere Dei Restauri (Milano: Electa, 1999), 6. 
26 Michael Robson, The Franciscans in the Middle Ages (Woodbridge: Boydell Press, 2009), 44-5.

27 Peter Brown, The Cult of the Saints: Its Rise and Function in Latin Christianity, Haskell Lectures on History of Religions. New Series, No. 2 (Chicago: University of Chicago Press, 1981), 9.

28 Brown, Cult of the Saints, 88.

29 Cited in Brown, Cult of the Saints, 4.

30 John Crook, The Architectural Setting of the Cult of Saints in the Early Christian West, C.300-1200 (Oxford: Clarendon Press, 2000), 17.

31 See Le Goff, Saint Francis of Assisi, in particular pp. 13-22 for a fuller account of the sources that account for Francis's life.

32 Le Goff, Saint Francis of Assisi, 61.

33 Le Goff, Saint Francis of Assisi, 3.

34 Linda Bird Francke, On the Road with Francis of Assisi: A Timeless Journey through Umbria and Tuscany, and Beyond (New York: Random House, 2005), 226.

35 E. Richard Gold, Body Parts: Property Rights and the Ownership of Human Biological Materials (Washington, DC: Georgetown University Press, 1996), 131.

36 Donal Cooper, "In Loco Tutissimo Et Firmissimo": The Tomb of St. Francis in History, Legend and Art', in The Art of the Franciscan Order in Italy, ed. William R. Cook, The Medieval Franciscans (Leiden: Brill, 2005): 1-38, at 5, and Figure 1.

37 Christopher Daniell, Death and Burial in Medieval England, 1066-1550 (London: Routledge, 1997), 120-1.

38 Cooper, 'In Loco Tutissimo Et Firmissimo'.

39 Cooper, 'In Loco Tutissimo Et Firmissimo', 12, n.37.

40 Cooper, 'In Loco Tutissimo Et Firmissimo', 12-13. See also Figure 3: Plan of the 1818 excavation of St Francis's tomb, and Figure 4: Cross-section of the 1818 excavation of St Francis's tomb.

41 Cited in Cooper, 'In Loco Tutissimo Et Firmissimo', 9.

42 Cooper, 'In Loco Tutissimo Et Firmissimo', 34 and n.124.

43 Walter, Placeways, 131.

44 Tim Ingold, Lines, a Brief History (London: Routledge, 2007), 80.

45 Cara Krmpotich, Joost Fontein, and John Harries, 'The Substance of Bones: The Emotive Materiality and Affective Presence of Human Remains', Journal of Material Culture 15, no. 4 (2010): 371-84, at 373.

46 Joanna Cannon, Religious Poverty, Visual Riches: Art in the Dominican Churches of Central Italy in the Thirteenth and Fourteenth Centuries (New Haven, CT: Yale University Press, 2013), 92.

47 Robert Pogue Harrison, The Dominion of the Dead (Chicago, IL: University of Chicago Press, 2003), xi.

48 Cadei, 'Architecture of the Basilica', 62. 
49 Cooper, 'In Loco Tutissimo Et Firmissimo', 22 and n.82.

50 Cooper, 'In Loco Tutissimo Et Firmissimo', 22.

51 Cooper, 'In Loco Tutissimo Et Firmissimo', 19-21, and Figure 9: High altar of the Lower Church with surrounding pergola, engraving from Francesco Antonio Maria Righini, OFM Conv., Provinciale Ordinis Fratrum Minorum S. Francisci Conventualium (Rome: Ex Typographia Joannis Zempel, 1771).

52 Cynthia Hahn, 'The Voices of the Saints: Speaking Reliquaries', Gesta 36, no. 1 (1997): 20-31, at 28.

53 Cooper, 'In Loco Tutissimo Et Firmissimo', 2.

54 Robert Macfarlane, Underland: A Deep Time Journey (London: Hamish Hamilton, 2019), 15.

55 Macfarlane, Underland, 37.

56 Gian Battista Vai and I. Peter Martini, Anatomy of an Orogen: The Apennines and Adjacent Mediterranean Basins (Dordrecht: Springer Science+Business Dordrecht, 2001), 15.

57 Vai and Martini, Anatomy of an Orogen, 267.

58 Cooper, 'In Loco Tutissimo Et Firmissimo', 34.

\section{Bibliography}

Brown, Peter. The Cult of the Saints: Its Rise and Function in Latin Christianity. Haskell Lectures on History of Religions. New Series, No. 2. Chicago: University of Chicago Press, 1981.

Cadei, Antonio. 'The Architecture of the Basilica.' In Saint Francis: Patriarchal Basilica in Assisi; Artistic Testimony, Evangelical Message, edited by Roberto Caravaggi, 4376. Milan: Gruppo Editoriale Fabbri, 1991.

Cannon, Joanna. Religious Poverty, Visual Riches: Art in the Dominican Churches of Central Italy in the Thirteenth and Fourteenth Centuries. New Haven, CT: Yale University Press, 2013.

Certeau, Michel de. The Practice of Everyday Life, translated by S. Rendell. Berkeley: University of California Press, 1984.

Cooper, Donal. " "In Loco Tutissimo Et Firmissimo": The Tomb of St. Francis in History, Legend and Art'. In The Art of the Franciscan Order in Italy, edited by William R. Cook. The Medieval Franciscans, 1-38. Leiden: Brill, 2005.

Crook, John. The Architectural Setting of the Cult of Saints in the Early Christian West, C.300-1200. Oxford: Clarendon Press, 2000.

Dalarun, Jacques. The Canticle of Brother Sun: Francis of Assisi Reconciled, translated by Philipe Yates. New York: Franciscan Institute, 2016.

Daniell, Christopher. Death and Burial in Medieval England, 1066-1550. London: Routledge, 1997. 
Francke, Linda Bird. On the Road with Francis of Assisi: A Timeless Journey through Umbria and Tuscany, and Beyond. New York: Random House, 2005.

Gold, E. Richard. Body Parts: Property Rights and the Ownership of Human Biological Materials. Washington, DC: Georgetown University Press, 1996.

Hahn, Cynthia. 'The Voices of the Saints: Speaking Reliquaries'. Gesta 36, no. 1 (1997): 20-31.

Harrison, Robert Pogue. The Dominion of the Dead. Chicago, IL: University of Chicago Press, 2003.

Ingold, Tim. Lines, a Brief History. London: Routledge, 2007.

Ingold, Tim. 'Ways of Mind-Walking: Reading, Writing, Painting. Visual Studies 25, no. 1 (2010): 15-23.

Korzybski, Alfred. Science and Sanity: An Introduction to Non-Aristotelian Systems and General Semantics, 5th ed. Brooklyn, NY: Institute of General Semantics, [1933] 1994.

Krmpotich, Cara, Joost Fontein, and John Harries. 'The Substance of Bones: The Emotive Materiality and Affective Presence of Human Remains. Journal of Material Culture 15, no. 4 (2010): 371-84.

La Verna Santuario Francescano, https://www.laverna.it/santuario/storia/ (accessed 23 September 2019).

Le Goff, Jacques. Saint Francis of Assisi, translated by Christine Rhone. London: Routledge, 2004.

Macfarlane, Robert. The Wild Places. London: Granta, 2007.

Macfarlane, Robert. The Old Ways: A Journey on Foot. London: Hamish Hamilton, 2012.

Macfarlane, Robert. Underland: A Deep Time Journey. London: Hamish Hamilton, 2019. Needham, Joseph. Science and Civilisation in China. Vol. 3, Mathemativs and the Sciences of the Heavens and the Earth. Cambridge: Cambridge University Press, 1970.

Robson, Michael. The Franciscans in the Middle Ages. Woodbridge: Boydell Press, 2009. Tilley, Christopher. A Phenomenology of Landscape. Oxford: Berg, 1994.

Vai, Gian Battista, and I. Peter Martini. Anatomy of an Orogen: The Apennines and Adjacent Mediterranean Basins. Dordrecht: Springer Science+Business Dordrecht, 2001.

van Os, H. W. 'St. Francis of Assisi as a Second Christ in Early Italian Painting'. Simiolus: Netherlands Quarterly for the History of Art 7, no. 3 (1974): 115-32.

Vauchez, Andre. Francis of Assisi: The Life and Afterlife of a Medieval Saint, translated by Michael F. Cusato. New Haven, CT: Yale University Press, 2012.

Walter, Eugene Victor. Placeways: A Theory of the Human Environment. Chapel Hill: University of North Carolina Press, 1988. 